\title{
Long-term outdoor exposure of artificial copper patina based on brochantite
}

Burě̌ R., Rak P., Stoulil J.

Department of Metals and Corrosion Engineering, University of Chemistry and Technology Prague

E-mail: stoulilj@vscht.cz

A typical green layer of patina starts to cover copper in atmosphere condition, which is aesthetically acceptable and also provides protective properties. This work investigates stability of the artificial patina layer based on sulphates prepared from a gaseous phase during two-year exposure in atmosphere condition. XRD and SEM were employed to verify the composition and morphology of artificial patina. Colour and patina coverage were compared before and after exposure also. According to results after 1 and 2 years of exposure, it is possible to see changing of hydroxyl sulphates to more stable brochantite and filling pores in the patina layer. There is almost no colour change, however lower patina coverage is slightly evident due to precipitation and abrasive effect.

\section{INTRODUCTION}

Copper is used in architecture thanks to its resistance to atmospheric corrosion, as elements of the façade and especially the copper roof, but also in art, especially in the form of bronze alloys. With long-term exposure to weather conditions, the surface of the copper is covered with a layer, which is subsequently modified into a patina and has both aesthetic and protective properties [1-3].

Corrosion is an electrochemical process and is therefore dependent on the presence and aggressiveness of the electrolyte. Aggressiveness is affected by the composition of the atmosphere and therefore allows the corrosion rate of copper to be compared in different types of atmosphere.

- Rural atmospheres: $0.2-0.6 \mu \mathrm{m} / \mathrm{a}$

- Urban atmospheres: $0.9-2.2 \mu \mathrm{m} / \mathrm{a}$

- Industrial atmospheres: $1.5-2.5 \mu \mathrm{m} / \mathrm{a}$

- Marine atmospheres: $0.7-1.5 \mu \mathrm{m} / \mathrm{a}$

The low corrosion rate in rural areas can be explained by the higher purity of the atmosphere, which has reduced salt content and thus the conductivity of the resulting electrolyte. On the contrary, the high corrosion rate in industrial areas is caused by pollution and the presence of sulphates, which decreased the $\mathrm{pH}$ of the electrolyte [1]. Sulphates may be present in acid rain at a concentration of 0.1-15 ppm, may further decrease the $\mathrm{pH}$ by adsorption and oxidation of $\mathrm{SO}_{2}$ in the electrolyte, or may be present as aerosol particles $[4,5]$.

The patina is a heterogeneous structure and arises in several stages. In the first phase, the exposed copper begins to be coated with a dark layer of $\mathrm{Cu}_{2} \mathrm{O}$ oxide (cuprite) approximately 5-10 $\mu \mathrm{m}$ thick, which changes the typical red colour of pure copper to brown and to black. This change takes months. Due to the action of the atmosphere, a layer containing $\mathrm{Cu}^{2+}$ is formed on this layer, which causes the colour change to blue-green [6]. The main phases usually found in this layer are posnjakite $\left[\mathrm{Cu}_{4}\left(\mathrm{SO}_{4}\right)(\mathrm{OH})_{6} \cdot \mathrm{H}_{2} \mathrm{O}\right]$, brochantite $\left[\mathrm{Cu}_{4}\left(\mathrm{SO}_{4}\right)(\mathrm{OH})_{6}\right]$, antlerite $\left[\mathrm{Cu}_{3}\left(\mathrm{SO}_{4}\right)(\mathrm{OH})_{4}\right]$, atacamite $\left[\mathrm{Cu}_{2} \mathrm{Cl}(\mathrm{OH})_{3}\right]$ and paratacamite $\left[\mathrm{Cu}_{2} \mathrm{Cl}(\mathrm{OH})_{3}\right]$ depending on the environment and the composition of the surrounding atmosphere. Sulphate-based patina is typical for urban and industrial areas, while chloride-based patina, whose colour tends to be lighter and more bluish, is found in coastal areas. The thickness of this second layer is around 40-50 $\mu \mathrm{m}$ [7-12].

Due to the reduction of the content of sulphates in the air, the time of formation of sulphate-based patina is currently being extended to decades. The content of sulphates in the atmosphere of the Czech Republic is in the range of $10-100 \mu \mathrm{g} \mathrm{m}^{-3}$ [13].

Carbonate-based patinas can also be found, but due to their higher solubility, they do not occur as often during atmospheric exposure and are more typical for archaeological finds [7].

The problem of artificial patinas is their low adhesion to the surface of the copper substrate, when damage occurs in the patina due to weather conditions. The reason may be its accelerated creation and the creation of weak bonds with the substrate. The artificial patina is more porous than the natural patina, so the effect of run off is easier. The abrasive effects of dust particles in the air and raindrops can also peels patina off in thin layers. 
If the artificial patina differs in its composition from the natural patina, other chemical reactions take place here, which affect the colour. Therefore, it is important that the artificial patina match as much as possible with the natural patina in terms of composition and morphology, which would ensure similar mechanical resistance and similar chemical behaviour affecting the colour change $[14,15]$.

Various techniques are used to characterize and describe the patina in order to determine its composition (XRD), morphology (SEM) and colour (spectrophotometry). Using these techniques is possible to observe different phases and describe its development during copper exposure in a corrosive environment [6, 16-18].

In this work, these techniques were used to investigate the behaviour of artificial patina based on brochantite during a two-year exposure in atmospheric conditions.

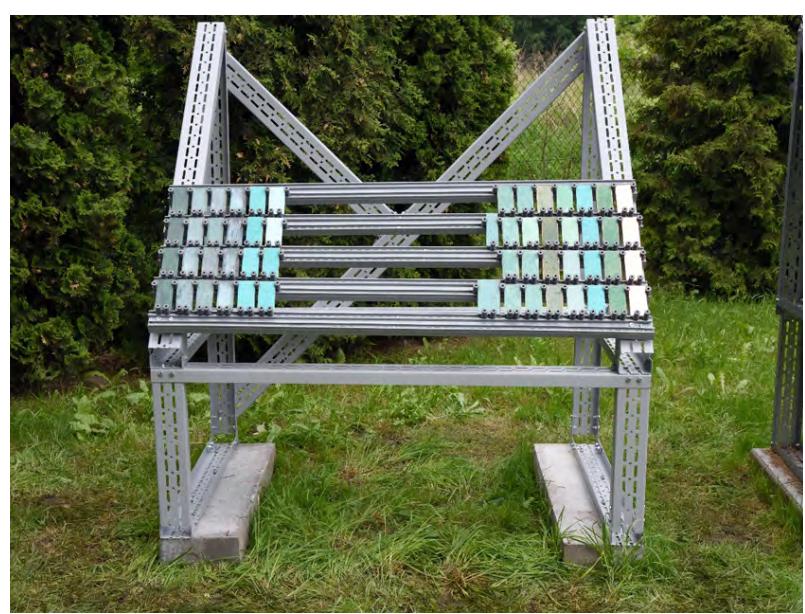

Fig. 1. Samples installation in Ostrava - Radvanice

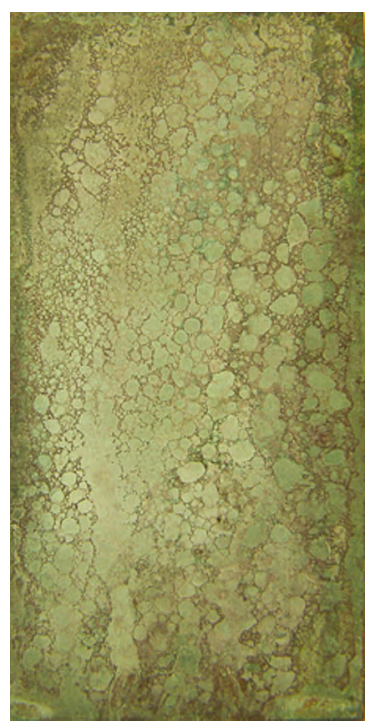

A

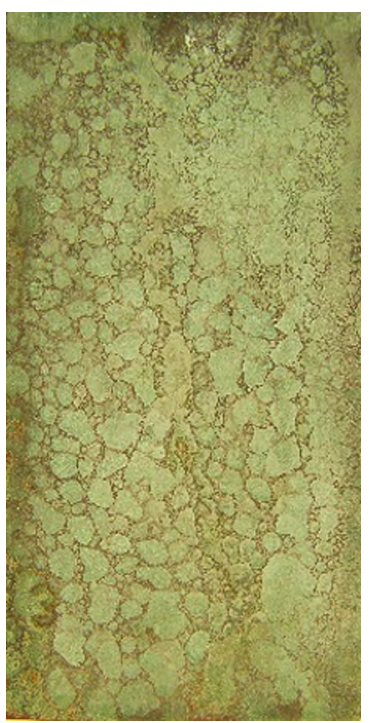

B

\section{EXPERIMENTAL}

In the exposure chamber described in the previous article, samples with artificial patina were prepared, which had different surface pretreatment [19]. Samples dimension $5 \times 10 \mathrm{~cm}$ with a ground surface using a brass brush (SFx marking), samples pre-patinated in solution $-100 \mathrm{ml} 25 \% \mathrm{NH}_{3}, 33 \mathrm{~g} \mathrm{Na}_{2} \mathrm{~S}$ and $250 \mathrm{ml} \mathrm{H}_{2} \mathrm{O}$ (marking $\mathrm{RxSF}$ ) and pre-oxidized samples were tested. The first set of samples was pre-oxidized in an oven at $150{ }^{\circ} \mathrm{C}$ for 60 minutes (marking TxSF) and the second with a hot air of $500{ }^{\circ} \mathrm{C}$ for 10 minutes (marking HxSF). 4 samples were prepared from each surface treatment ( 2 for 1 year exposure and 2 for 2 years exposure). The prepared samples were exposed in a 301 chamber for 14 days under predefined conditions. The temperature during the exposure was $40{ }^{\circ} \mathrm{C}$, the volume of water in the chamber, which provides $100 \%$ humidity, was 51 and the input dose of $\mathrm{SO}_{2}$ was $100 \mathrm{ml}\left(8.9 \mathrm{~g} \mathrm{~m}^{-3}\right)$. The condensation (16 hours) and drying phases ( 8 hours) were alternated during the cycle.

The obtained patina was photographically documented and described in terms of composition (XRD, X'Pert Pro, PANalytical, EA Almelo, Holland), morphology (SEM-VEGA3 LMU, TESCAN, Brno, Czech Republic), colour (spectrophotometry - CM-700d, Minolta, Tokyo, Japan) and homogeneity (image analysis - QuickPhoto Industrial, 3.2).

For long-term exposure of artificial patina in atmospheric conditions (Fig. 1) the locality Ostrava - Radvanice was chosen, where the concentration of $\mathrm{SO}_{2}$ in the air is around $10-15 \mathrm{\mu g} \mathrm{m}^{-3}$ and exceptionally in the short term it can approach the limit of $100 \mu \mathrm{g} \mathrm{m}^{-3}[20,21]$. The first set of samples was analyzed after 1 year of exposure and the second after 2 years.

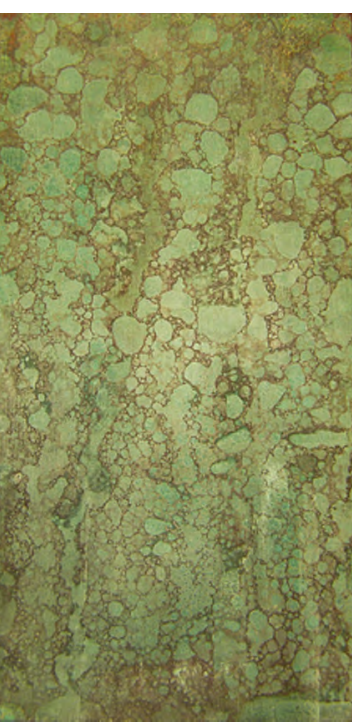

C

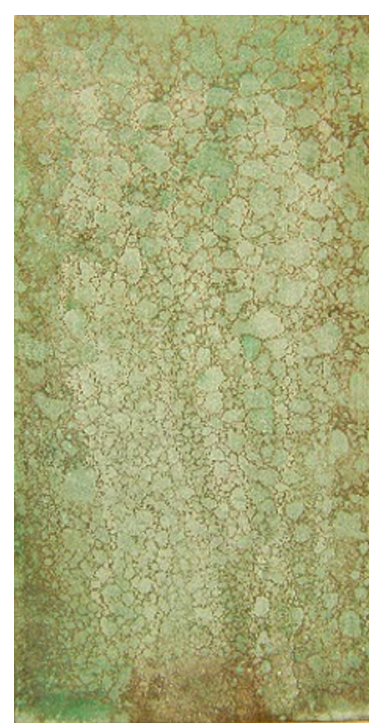

D

Fig. 2. Samples prior to patination $A$ and $B$ ground surface, $C$ and $D$ preoxidized in the oven 


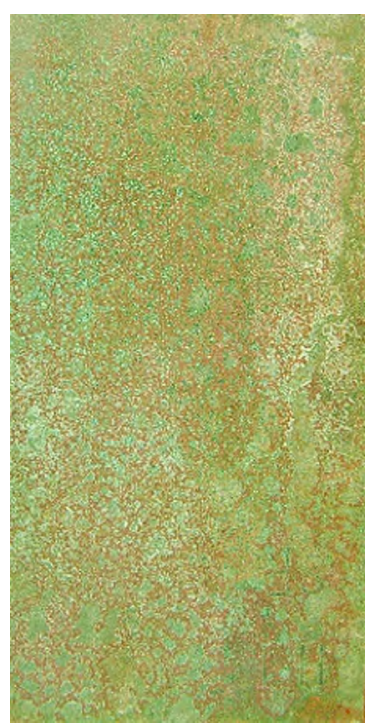

A

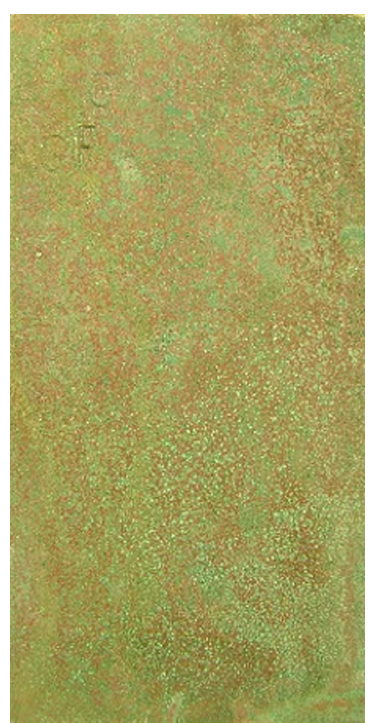

B

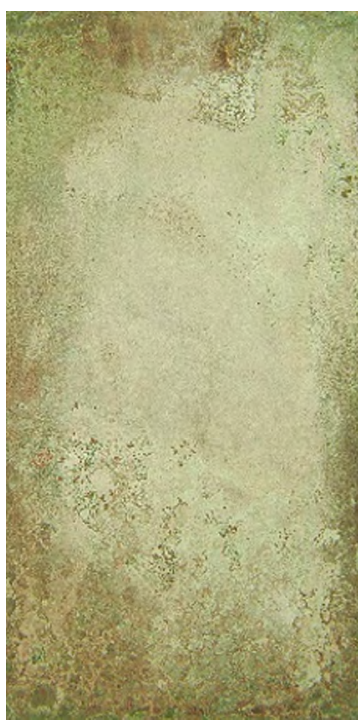

C

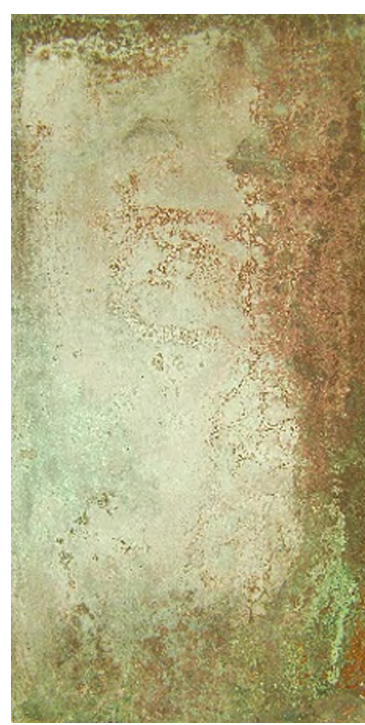

D

Fig. 3. Samples prior to patination A and B preoxidized with hot air, $C$ and D prepatinated in the solution

\section{RESULTS}

\section{Artificial patina}

Figures 2 and 3 show selected samples with artificial patina, which was documented and compared with natural patina in terms of morphology, composition and colour. As follows from the literature, the natural patina is less porous than the artificial patina, which is also confirmed by observations at SEM (Figs. 4 and 5). The XRD of artificial patina confirmed that the patina consists mainly of hydroxyl sulphates and that brochantite is represented as the main component (Fig. 6). Regarding the colour of the artificial patina, which was compared with the historical patina from the roof of Queen Anne's Summer Palace at Prague Castle, it was found that the shade of green, i.e. components $\mathrm{a}^{*}$ and $\mathrm{b}^{*}$ are close to the natural brochantite (Fig. 7), however, the resulting colour is affected by component $\mathrm{L}^{*}$, which expresses the luminosity. Its value is lower than that of the natural patina, which explains the darker appearance of the artificial patina. The above-mentioned procedure in the exposure chamber managed to cover the surface of the copper samples with an artificial patina of approximately $74-88 \%$ (Tab. 1).

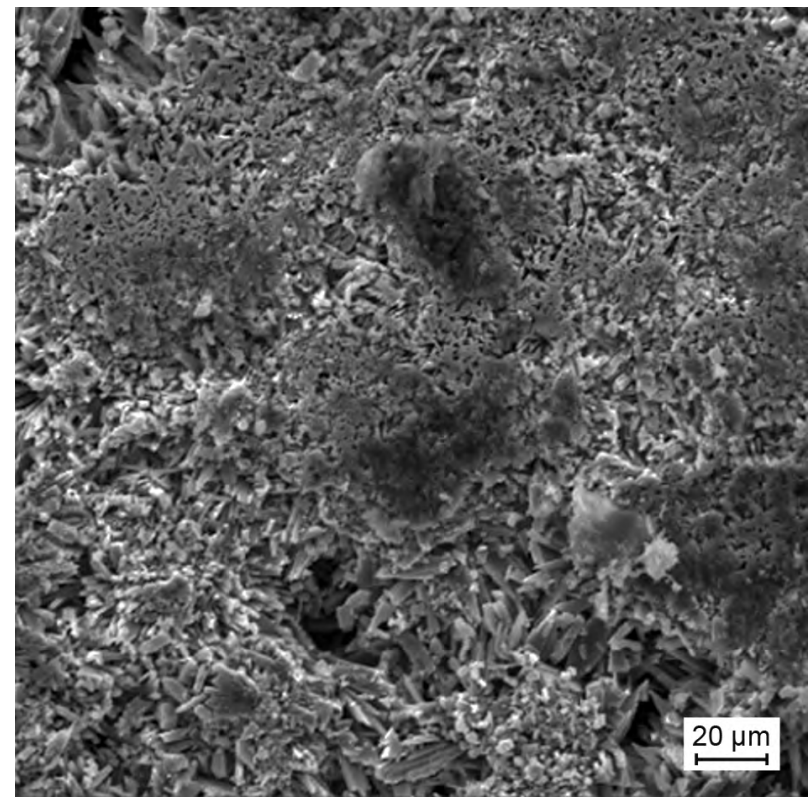

Fig. 4. SEM image - artificial patina, surface preoxidized in the oven

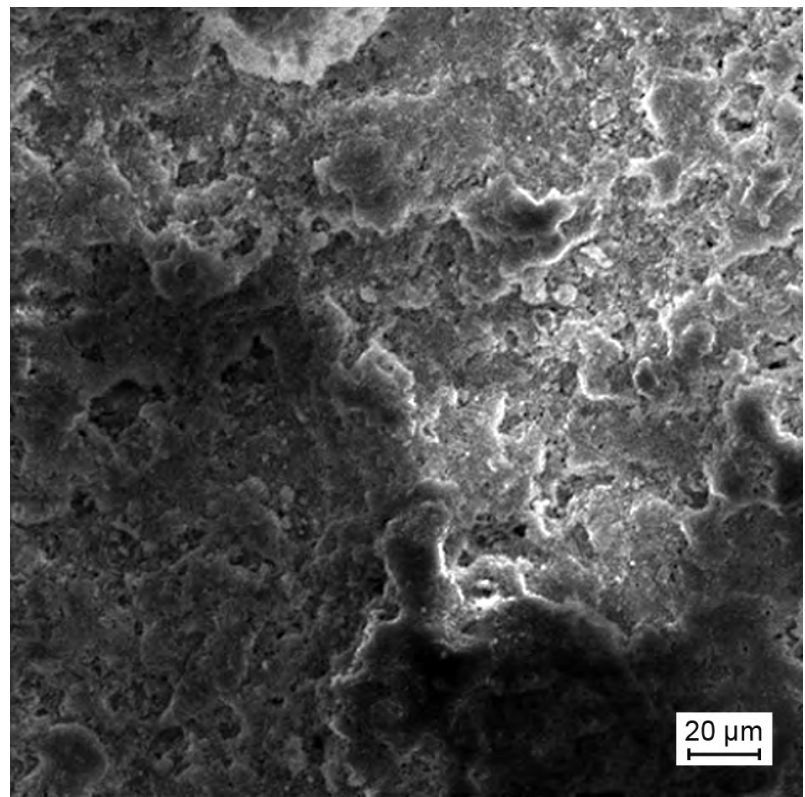

Fig. 5. Natural patina 
Tab. 1. Area covered with patina [\%]

\begin{tabular}{|l|c|c|c|c|c|c|c|c|}
\hline Set of samples & \multicolumn{2}{|c|}{ 1. } & \multicolumn{2}{c|}{ 2. } & \multicolumn{3}{c|}{ 3. } & \multicolumn{2}{c|}{ 4. } \\
\hline Orientation of the exposed side of the sample & upper & lower & upper & lower & upper & lower & upper & lower \\
\hline Ground surface & 86 & 79 & 86 & 74 & 74 & 88 & 72 & 81 \\
\hline Preoxidized in the oven & 84 & 73 & 74 & 73 & 77 & 80 & 64 & 89 \\
\hline Preoxidized with hot air & 64 & 71 & 71 & 79 & 82 & 51 & 71 & 40 \\
\hline Prepatinated in the solution & 77 & 48 & 96 & 26 & 52 & 75 & 56 & 81 \\
\hline
\end{tabular}

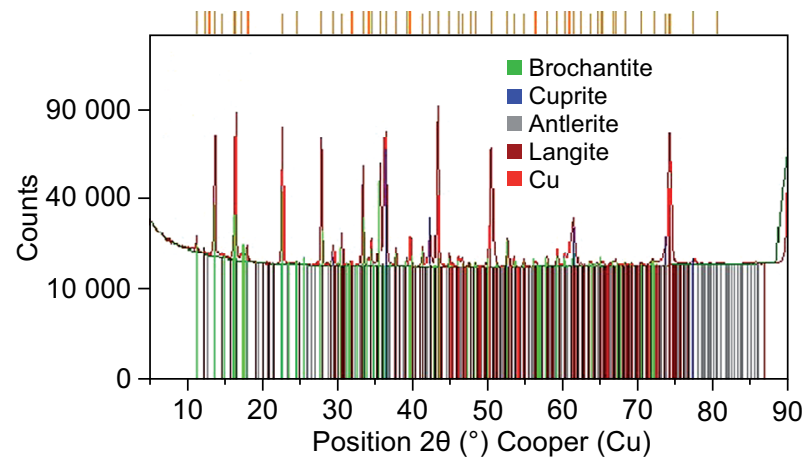

Fig. 6. XRD of artificial patina with surface preoxidized in oven (sample T4SF)
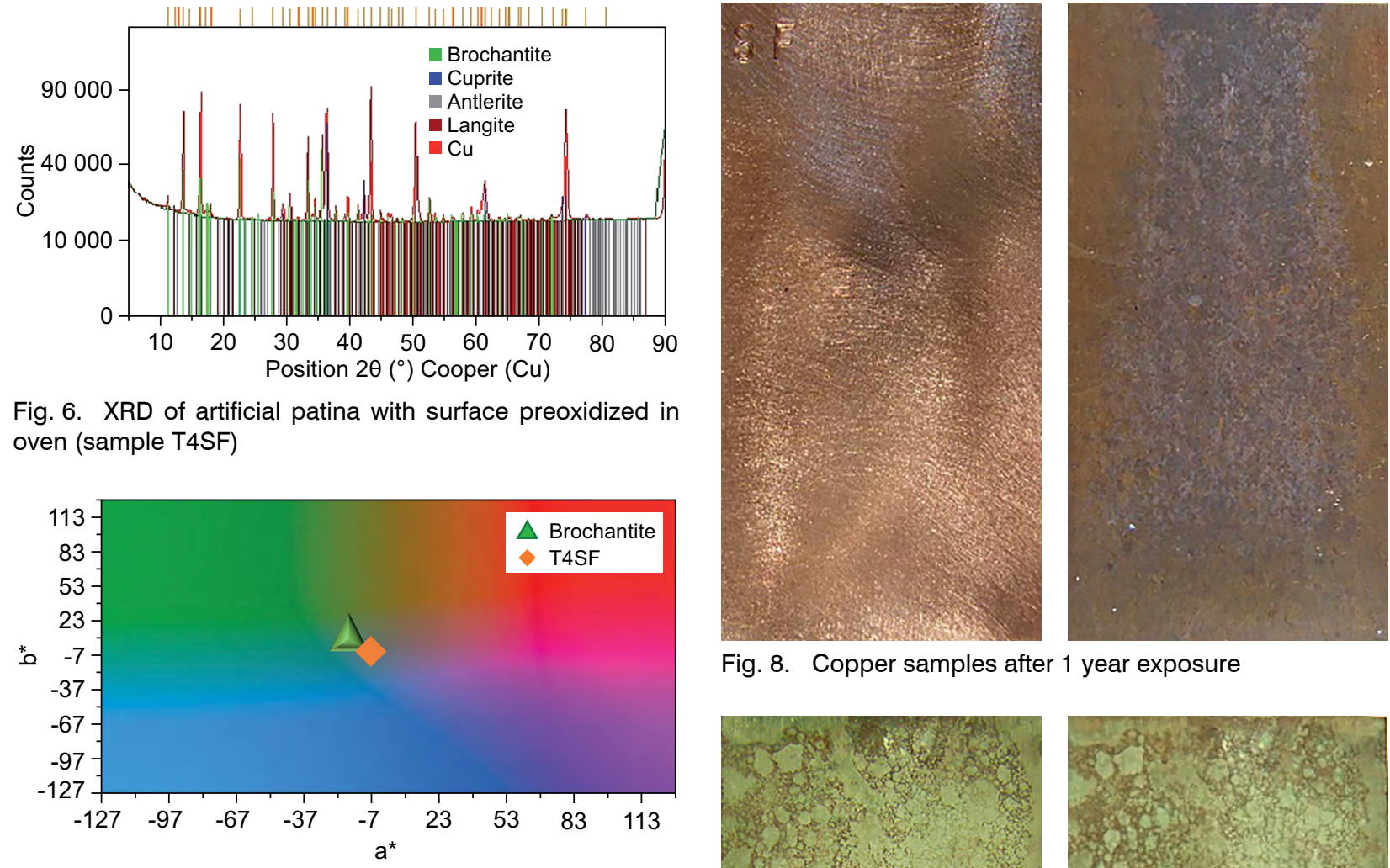

Fig. 8. Copper samples after 1 year exposure

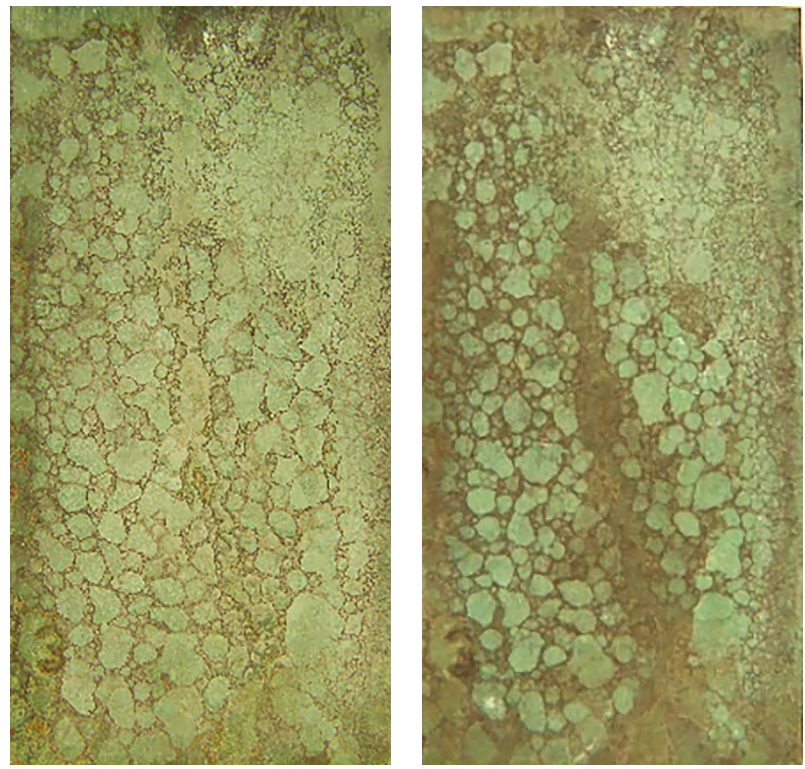

Fig. 9. Samples of artificial patina with ground surface after 1 year exposure

derside of a set of HxSF samples preoxidized by a stream of hot air means that the patinated area has increased and thus a new patina has been formed. The colour fastness of the patina is good (Fig. 14.), but a darker appearance against the natural patina is still visible. 

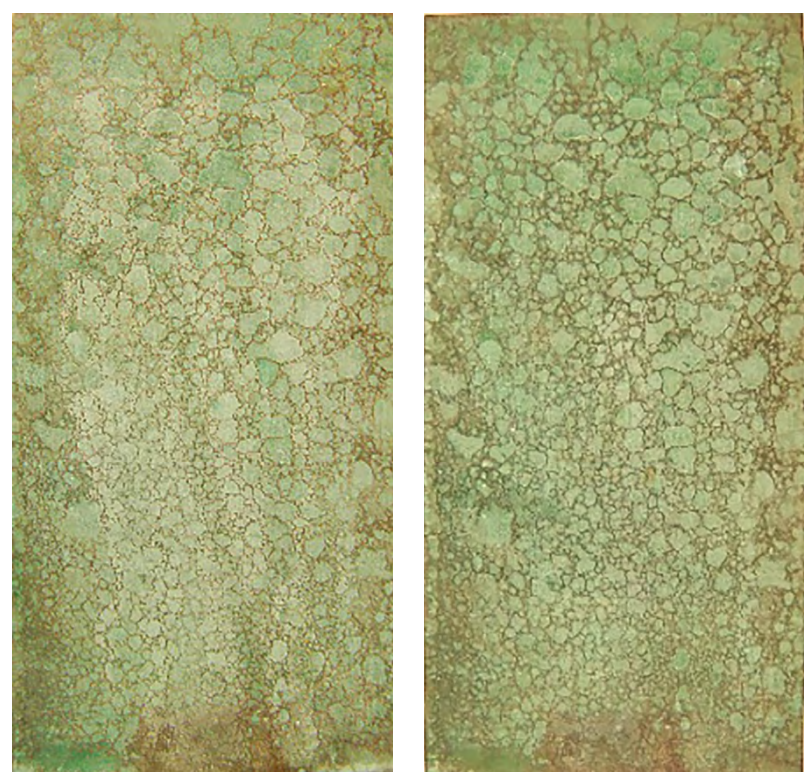

Fig. 10. Samples of artificial patina with surface preoxidized in the oven after 1 year exposure
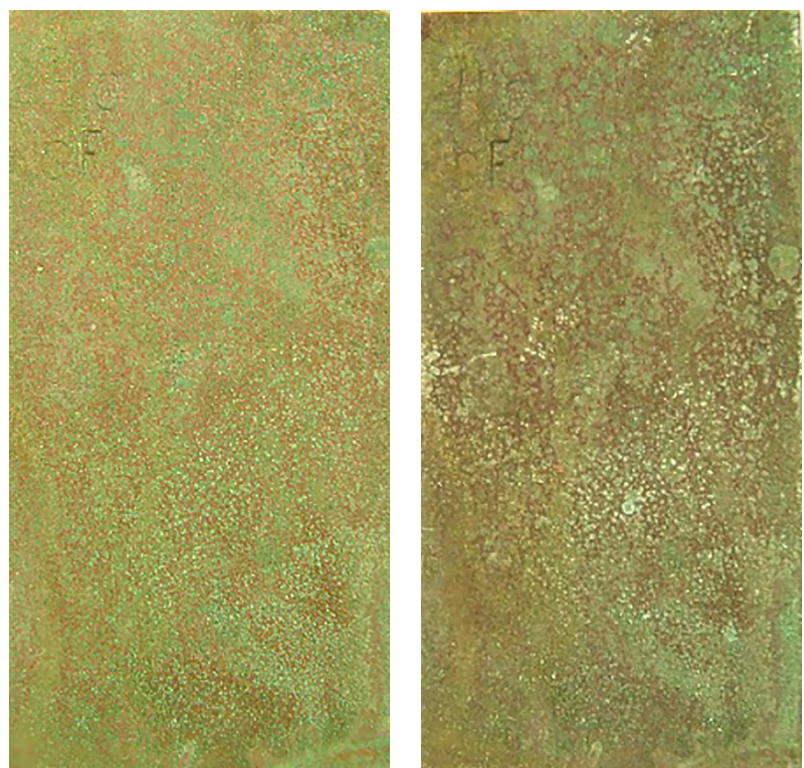

Fig. 11. Samples of artificial patina with surface preoxidized with hot air after 1 year exposure

Tab. 2. XRD analysis after the $1^{\text {st }}$ year of exposure

\begin{tabular}{|c|c|}
\hline $\begin{array}{c}\text { Composition of } \\
\text { original sample }\end{array}$ & $\begin{array}{c}\text { Composition } \\
\text { after 1. year }\end{array}$ \\
\hline brochantite $70 \%$ & brochantite $90 \%$ \\
\hline cuprite $14 \%$ & cuprite $8 \%$ \\
\hline antlerite $2 \%$ & copper $2 \%$ \\
\hline langite $1 \%$ & \\
\hline copper $13 \%$ & \\
\hline
\end{tabular}

Koroze a ochrana materiálu 64(3) 87-94 (2020)
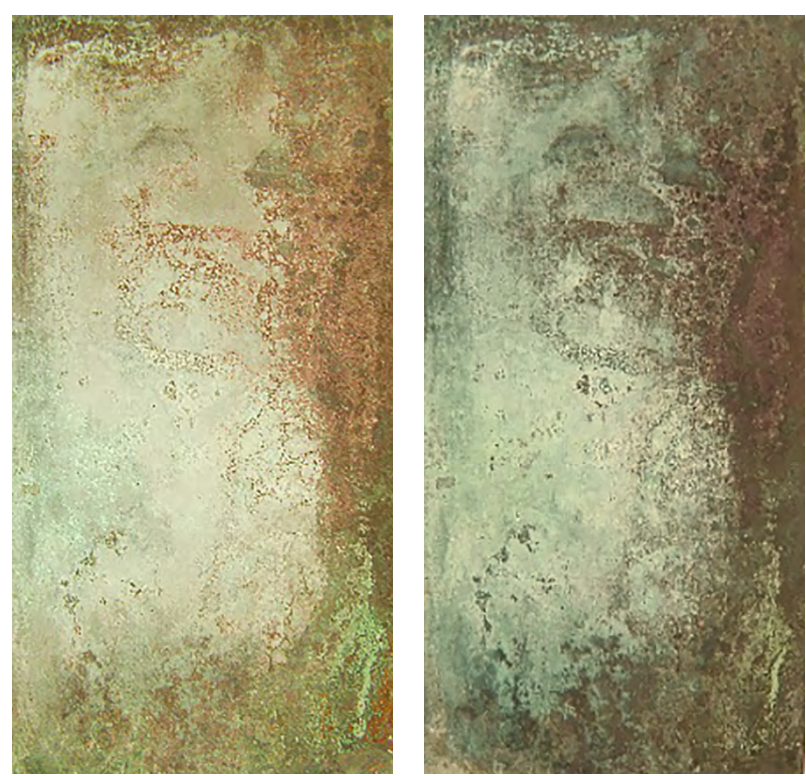

Fig. 12. Samples of artificial patina with surface prepatinated in the solution after 1 year exposure

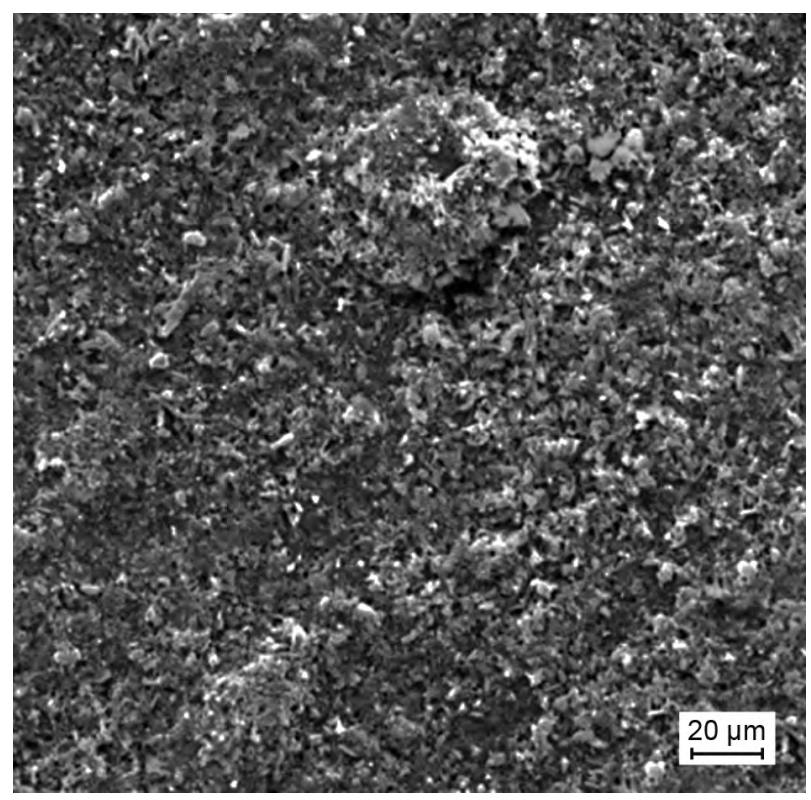

Fig. 13. SEM of sample of artificial patina with surface preoxidized in the oven after 1 year exposure

Tab. 3. Average loss of patina area after $1^{\text {st }}$ year of exposure $[\%]$

\begin{tabular}{|l|c|c|}
\hline \multirow{2}{*}{} & \multicolumn{2}{|c|}{$\begin{array}{c}\text { Orientation of the exposed } \\
\text { side of the sample }\end{array}$} \\
\cline { 2 - 3 } & upper & lower \\
\hline Ground surface & 13 & 9 \\
\hline Preoxidized in the oven & 15 & 6 \\
\hline Preoxidized with hot air & 16 & -22 \\
\hline Prepatinated in the solution & 10 & 4 \\
\hline
\end{tabular}

DOI: $10.2478 / \mathrm{kom}-2020-0013$ 


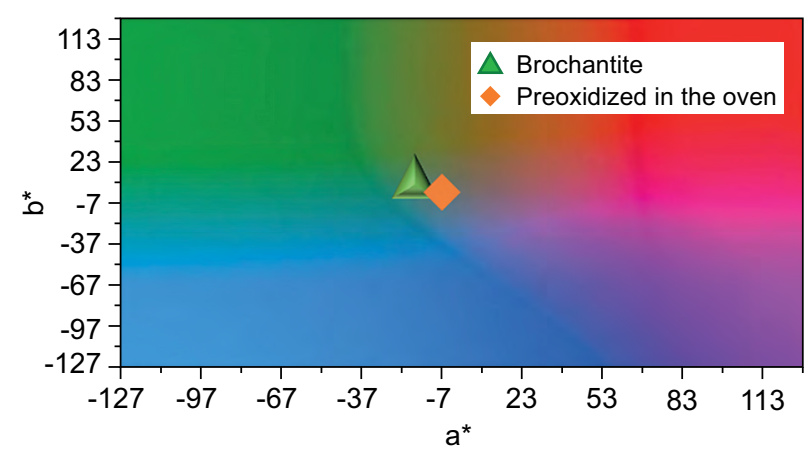

Fig. 14. Comparison by reflectance spectrophotometry of artificial patina with surface preoxidized in the oven and natural patina

\section{Exposure after the $2^{\text {nd }}$ year}

After the second year of exposure, it is possible to observe another course of darkening of the copper covered with cuprite (Fig. 15), which leads almost to blackening of the surface, as described in the literature [6]. XRD analysis showed the presence of posnjakite in this layer (Tab. 4), which is further converted to brochantite or antlerite. In Fig. 16-19 is a comparison of samples with different surface pretreatment before and after the exposure. The SEM image (Fig. 20) documents the condition of the patina and it is possible to observe the closure of the patina surface. According to the results in Tab. 5 it is clear that it is still a brochantite patina and no significant changes in composition due to weathering take place. Thus, it can be noted that the patina is relatively stable in terms of composition and colour (Fig. 21). However, the effect of weather conditions on the patina area is obvious from the results in Tab. 6, as there is a further reduction of the patinated area due to insufficient bonding with the substrate, which is a problem especially
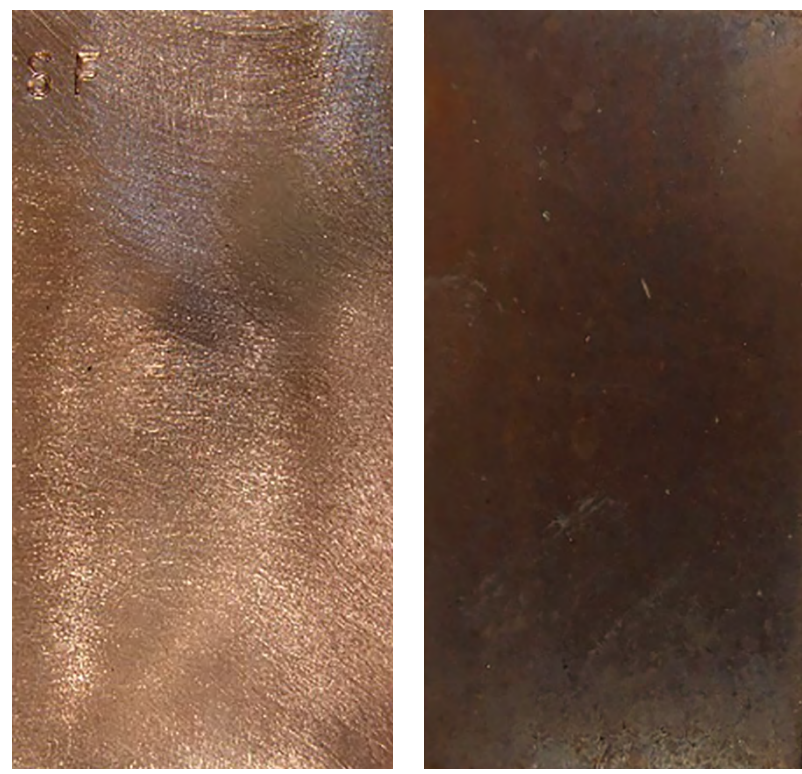

Fig. 15. Copper samples after 2 years of exposure for samples pre-patinated in solution. A comparison of the results of patina loss after 1 and 2 years of exposure shows an approximately uniform decrease on the underside of ground samples and samples pre-oxidized in the oven. On the contrary, on the upper side with effects of

Tab. 4. XRD of $\mathrm{Cu}$ samples after the $2^{\text {nd }}$ year of exposure

\begin{tabular}{|l|c|}
\hline Cu & $65 \%$ \\
\hline Cuprite & $30 \%$ \\
\hline Posnjakite & $5 \%$ \\
\hline Brochantite & $2 \%$ \\
\hline
\end{tabular}
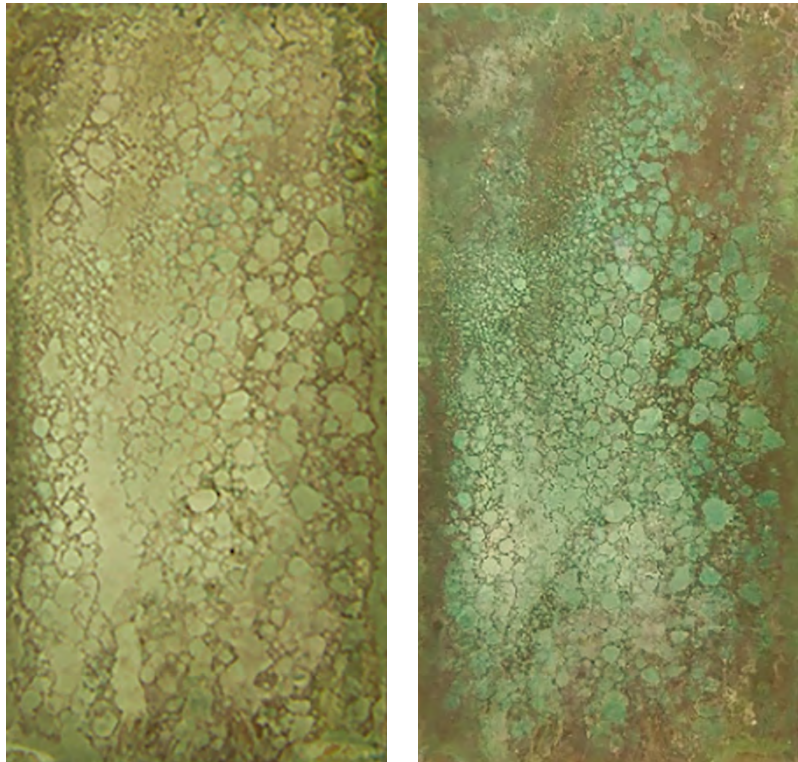

Fig. 16. Samples of artificial patina with surface preoxidized in the oven after 2 year exposure
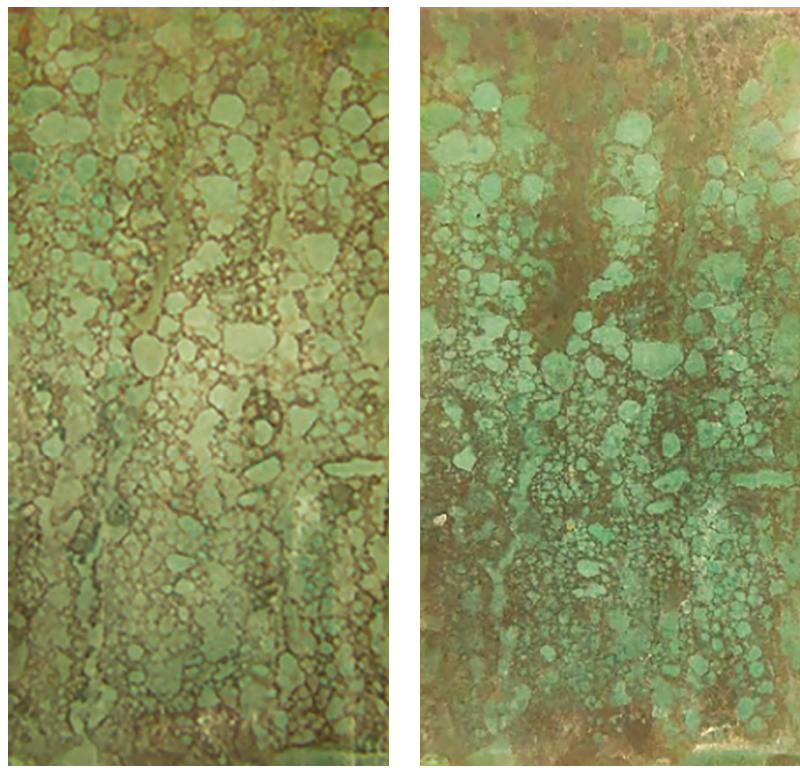

Fig. 17. Samples of artificial patina with ground surface after 2 year exposure 
run off, this process seems to slow down. This can be explained by the fact that at the same time as the patina is washed away, a natural patina can develop, as show the results in Table 4, however, the rate of new patina formation does not reach the rate of patina loss.
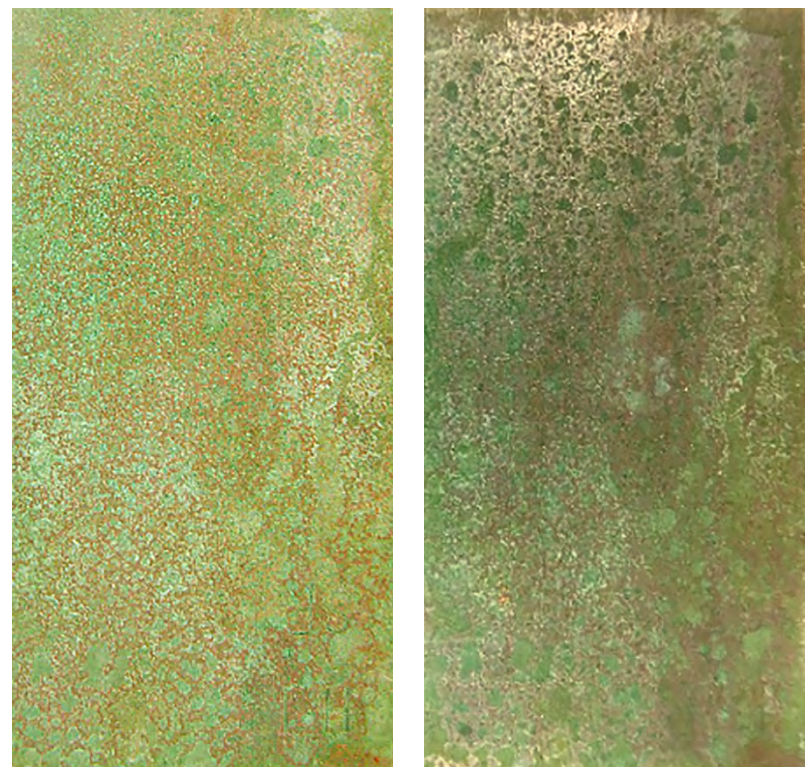

Fig. 18. Samples of artificial patina with surface preoxidized with hot air after 2 year exposure
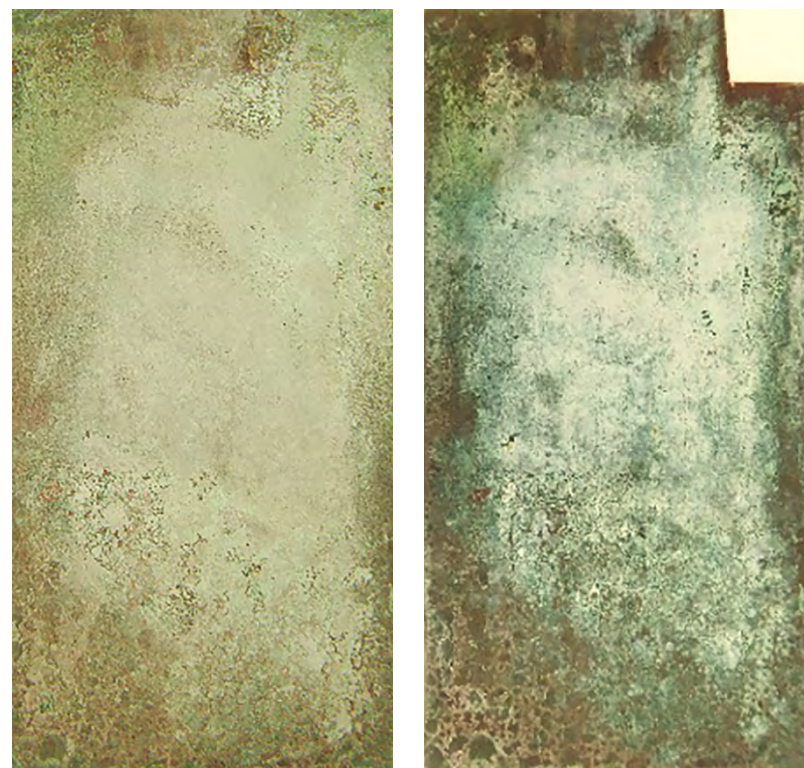

Fig. 19. Samples of artificial patina with surface prepatinated in the solution after 2 year exposure

\section{CONCLUSION}

The artificial patina created from the gaseous phase in the exposure chamber is similar to the natural patina that forms in urban and industrial areas. Its main component is a stable phase of brochantite and its colour is very close to natural patina. The main disadvantage

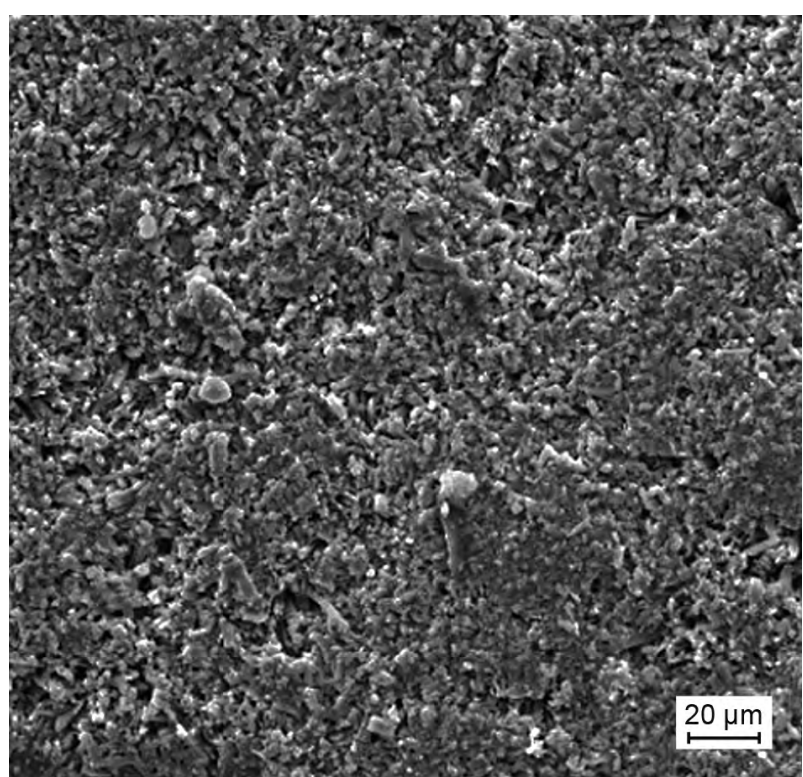

Fig. 20. SEM of sample of artificial patina with surface preoxidized in the oven after 2 year exposure

Tab. 5. XRD analysis after the $2^{\text {nd }}$ year

\begin{tabular}{|c|c|}
\hline $\begin{array}{c}\text { Composition of original } \\
\text { sample }\end{array}$ & Composition after 2. year \\
\hline brochantite $70 \%$ & brochantite $70 \%$ \\
\hline cuprite $14 \%$ & cuprite $15 \%$ \\
\hline antlerite $2 \%$ & $\mathrm{Cu} 15 \%$ \\
\hline langite $1 \%$ & \\
\hline copper $13 \%$ & \\
\hline
\end{tabular}

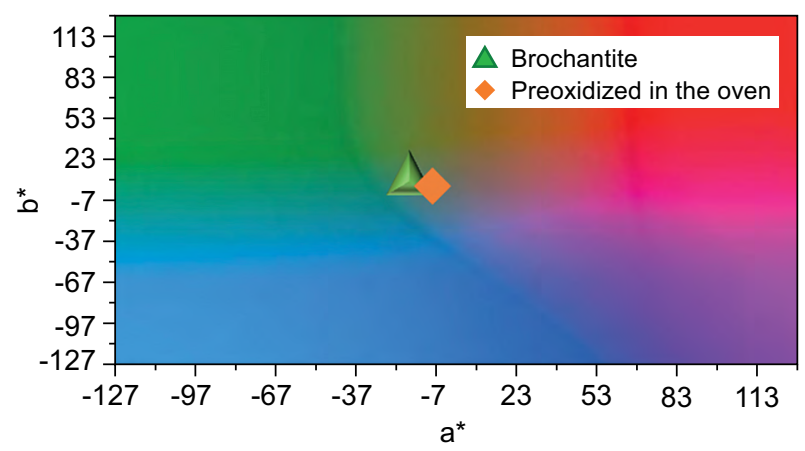

Fig. 21. Results of reflectance spectrophotometry

Tab. 6. Average loss of patina area after $2^{\text {nd }}$ year of exposure [\%]

\begin{tabular}{|l|c|c|}
\hline \multirow{2}{*}{} & $\begin{array}{c}\text { Orientation of the exposed } \\
\text { side of the sample }\end{array}$ \\
\cline { 2 - 3 } & upper & lower \\
\hline Ground surface & 10 & 19 \\
\hline Preoxidized in the oven & 7 & 17 \\
\hline Preoxidized with hot air & 15 & 13 \\
\hline Prepatinated in the solution & 32 & 7 \\
\hline
\end{tabular}


that affects the adhesion to the substrate is its porosity and effects of run off can occur simultaneously with abrasive effects. However, this condition has improved with the time the patina has been exposed and is probably supplemented by the formation of a natural patina. Pre-oxidation of copper helps to achieve a more even patination and, in the longer term, when done correctly, contributes to the easier formation of a natural patina.

\section{Acknowledgments}

Financial support from Czech Ministry of Culture in programme NAKI II under the project number DG16P02H051 is gratefully acknowledged.

\section{REFERENCES}

1. De la Fuente, D., et al., Morphological study of 16-year patinas formed on copper in a wide range of atmospheric exposures. Corrosion Science 2008, 50 (1), 268-285.

2. Fonseca, I. T. E., et al., The atmospheric corrosion of copper at two sites in Portugal: a comparative study. Corrosion Science 2004, 46 (3), 547-561.

3. Robbiola, L., et al., Morphology and mechanisms of formation of natural patinas on archaeological $\mathrm{Cu}-\mathrm{Sn}$ alloys. Corrosion Science 1998, 40 (12), 2083-2111.

4. Fitzgerald, K. P., et al., The chemistry of copper patination. Corrosion Science 1998, 40 (12), 2029-2050.

5. Zhang, Q., et al., Variability of $\mathrm{SO}_{2}$ in an intensive fog in North China Plain: Evidence of high solubility of $\mathrm{SO}_{2}$. Particuology 2013, 11 (1), 41-47.

6. Leygraf, C., et al., The origin and evolution of copper patina colour. Corrosion Science 2019, 157, 337-346.

7. Graedel, T. E., et al., Copper Patinas Formed in the Atmosphere .1. Introduction. Corrosion Science 1987, 27 (7), 639-657.
8. Aastrup, T., et al., In situ studies of the initial atmospheric corrosion of copper influence of humidity, sulfur dioxide, ozone, and nitrogen dioxide. J. Electrochem. Soc. 2000, 147 (7), 2543-2551.

9. Franceschi, E., et al., Colour measurements on patinas and coating system for outdoor bronze monuments. Journal of Cultural Heritage 2006, 7 (3), 166-170.

10. Kratschmer, A., et al., The evolution of outdoor copper patina. Corrosion Science 2002, 44 (3), 425-450.

11. Sandberg, J., et al., Corrosion-induced copper runoff from naturally and pre-patinated copper in a marine environment. Corrosion Science 2006, 48 (12), 4316-4338.

12. Watanabe, M., et al., Evolution of patinas on copper exposed in a suburban area. Corrosion Science 2007, 49 (2), 766-780.

13. Kreislova, K.; Geiplova, H., Prediction of the long-term corrosion rate of copper alloy objects. Mater. Corros. 2016, 67 (2), 152-159.

14. Knotková, D., et al. In Transformation of the artificial green patina layers., AKI, Pelhřimov, Czech Republic, Pelhřimov, Czech Republic, 2001.

15. Atrens, A.; Nairn, J. Artificial Patina. PCT Patent Application No. PCT/AU95/00236, 21. April, 1995.

16. Constantinides, I., et al., Surface characterization of artificial corrosion layers on copper alloy reference materials. Appl. Surf. Sci. 2002, 189 (1-2), 90-101.

17. Guadagnini, L., et al., The use of scanning electrochemical microscopy for the characterisation of patinas on copper alloys. Electrochimica Acta 2011, 56 (19), 6598-6606.

18. Wallinder, I. O.; Leygraf, C., A study of copper runoff in an urban atmosphere. Corrosion Science 1997, 39 (12), 2039-2052.

19. Bures, R., et al., Artificial Patination of Copper and Copper Alloys in Wet Atmosphere with Increased Content of $\mathrm{SO}_{2}$. Coatings 2019, 9 (12).

20. Ostrava - Radvanice ZÚ. http://portal.chmi.cz/files/portal/ docs/uoco/isko/tab_roc/2019_enh/pollution_overview/ mp_TOREK_SO2_CZ.html.

21. Ostrava - město. http://portal.chmi.cz/files/portal/docs/ uoco/isko/tab_roc/2019_enh/pollution_hdqy/CZTOS $\mathrm{SO} 2$ CZ.html. 